\title{
Decreased Implantation Number After In Utero Artificial Insemination Can Reflect an Impairment of Fertility in Adult Male Rats After Exogenous Leptin Exposure
}

Reproductive Sciences

2017, Vol. 24(2) 234-24I

(C) The Author(s) 2016

Reprints and permission:

sagepub.com/journalsPermissions.nav DOI: $10.1|77 /| 9337|9| 16653678$

journals.sagepub.com/home/rsx

@SAGE

\author{
Carla D. B. Fernandez, MSc, PhD ${ }^{1,2}$, Glaura S. A. Fernandes, MSc, PhD', \\ Ana Paula A. Favareto, MSc, PhD', Juliana E. Perobelli, PhD', \\ Marciana Sanabria, MSc, PhD', and Wilma D. G. Kempinas, MSc, PhD'
}

\begin{abstract}
Leptin is a protein secreted by the adipocytes, which serves as a link between fat and brain. Its main action is to decrease appetite and increase energy expenditure, but it is also involved in the control of different neuroendocrine systems, including gonadal axis. Although the effects of leptin deficiency on reproduction are well recognized, the effect of excess leptin on male reproductive function is not clear. The aim of this study was to evaluate fertility and sperm parameters of male rats exposed to exogenous leptin. A group of adult male rats received exogenous leptin intraperitoneally $(30 \mu g / \mathrm{kg} / \mathrm{day})$ for 42 days, and a control group received only the vehicle during the same period. After the treatment, animals were evaluated for sperm count, sperm motility, and fertility after intrauterine artificial insemination. There was no statistically significant difference between the groups related to sperm production, sperm concentration, and sperm motility. However, fertility evaluation after artificial insemination showed a quantitative decrease in the uterus plus fetuses weight, number of implantation sites, and number of live fetuses. The fertility potential showed a reduction of about $40 \%$, whereas the preimplantation loss rate increased more than 2 -fold in leptin-treated animals. In conclusion, leptin administration to nonobese male rats impairs ability of treated animals to generate offspring, since the occurrence of implantation was diminished. So leptin can impair sperm quality, affecting the reproductive capacity.
\end{abstract}

\section{Keywords}

leptin, implantation rate, fertility, male reproduction.

\section{Introduction}

Recently, many efforts have been made to understand how peripheral metabolic hormones mediate aspects of the neuroendocrine reproductive axis, with a particular interest to leptin. ${ }^{1,2}$ Leptin is a $16-\mathrm{kDa}$ protein transcribed from the $o b$ gene and secreted by the adipocytes, ${ }^{3,4}$ mainly in white adipose tissue, ${ }^{5}$ serving as a link between fat and brain. Long-term intake of high-fat diet induces increase in plasma leptin. ${ }^{6,7}$ The word leptin is derived from the Greek word "leptos" that means thin. ${ }^{5,3}$ Leptin achieves most of its metabolic effects by interaction with specific receptors located in the central nervous system and in peripheral tissues. ${ }^{5}$ The main action of leptin is to decrease appetite and increase energy expenditure, ${ }^{8}$ but it is also involved in the control of different neuroendocrine systems, acting as a regulatory signal for growth, adrenal, thyroid, and gonadal axes, ${ }^{2,9}$ in last case acting as a metabolic link between nutrition and fertility.

In a recent publication, Teerds and coauthors ${ }^{10}$ suggested infertility in overweight/obese males may be explained by leptin insensitivity. Another recent study described an effect of leptin on nutritional support exerted by the Sertoli cells upon the developing germ cells. ${ }^{11}$ The glycolytic activity of Sertoli cells is very important for normal spermatogenesis, and Martins and coauthors ${ }^{11}$ showed that leptin can directly act on these cells modulating their metabolic behavior, leading to

\footnotetext{
' Laboratory of Reproductive and Developmental Biology and Toxicology, Department of Morphology, Institute of Biosciences, UNESP-Univ Estadual Paulista, Botucatu, Brazil

${ }^{2}$ Pró-Reitoria de Pesquisa e Pós-Graduação, Central de Laboratórios de Ciências e Tecnologia Ambiental—Laboratório de Toxicologia Experimental, Universidade Sagrado Coração, SP, Brazil
}

Corresponding Author:

Carla D. B. Fernandez, Pró-Reitoria de Pesquisa e Pós-Graduação, Central de Laboratórios de Ciências e Tecnologia Ambiental-Laboratório de Toxicologia Experimental, Universidade Sagrado Coração, CEP I701 I-I60, Rua Irmã Arminda 10-50, Bloco K, Bauru, SP, Brazil.

Email: carladbfernandez@gmail.com 
a drastic decrease in acetate production by Sertoli cells, which is probably linked to lipid synthesis in developing germ cells. In men, the occurrence of varicocele is related to increased leptin concentration in serum and seminal plasma, and this increase is inversely related to sperm concentration and motility. ${ }^{12}$ In rats with experimental varicocele, an increase of leptin and receptor expression is sight in the testis, inversely related to testicular weight, tubule diameter, and epithelium height. ${ }^{13}$

It is well known that the absence of biological actions of leptin, due to mutations in the $o b$ gene (ob/ob mice) or in the leptin receptor gene ( $d b / d b$ mice), leads to infertility in males and females. ${ }^{14-16}$ In the same way, Akita mouse is a model of type 1 diabetes that own a mutation in insulin (ins2) gene, and it is an useful model for diabetes-related male infertility. The homozygous Akita mouse is severely diabetic, infertile, present testicular atrophy, disrupted spermatogenesis, and absence of mature spermatozoa, but after treatment with leptin, the reproductive problems are rescued near to wild-type mice. ${ }^{17}$ Leptinreceptor-deficient Zucker rat presented impairment on sperm production during puberty and increased sperm DNA fragmentation. ${ }^{18}$ Interestingly, studies have shown that the treatment of mutant mice with exogenous leptin restores fertility in both sexes. ${ }^{19,20}$ In humans, there is an inverse correlation between leptin levels and the age at menarche in women; and in men, the lack of endogenous leptin is associated to hypogonadism and absence of pubertal development. ${ }^{9}$

Leptin levels are augmented in obese human, and some studies have associated the increased body mass index (BMI) to poor sperm quality, ${ }^{21}$ decreased sperm concentration, ${ }^{22}$ decreased normal motile sperm cells, and increased DNA fragmentation index. ${ }^{23}$ Alves and coauthors ${ }^{24}$ revised several studies that show the influence of overweight and obesity on male reproduction, as well as the role of leptin and other metabolic hormones, such as ghrelin and glucagon-like peptide 1 in male fertility. Although the effects of leptin deficiency on reproduction are well recognized, ${ }^{25}$ the effect of excess leptin on male reproductive function is not entirely understood. Our previous study showed that obesity leads to significant increase in serum leptin levels, low sperm quality, and impairment in male fertility. ${ }^{7}$ Exogenous leptin treatment, in nonobese Sprague-Dawley rats, for 42 days, leads to a decrease in sperm count and an increase in percentage of abnormal sperm, ${ }^{26}$ showing that leptin could play a role in the reported negative correlation between BMI and sperm quantity and quality.

In an attempt to understand more deeply the relation between leptin and the male reproductive system, including fertility, the aim of the present study was evaluate fertility and sperm parameters of male rats exposed to exogenous leptin.

\section{Materials and Methods}

\section{Animals and Treatment}

Male ( $\mathrm{n}=24,100$ days old) and female $(\mathrm{n}=36,80$ days old) Wistar rats were supplied by São Paulo State University
Animal Center, Botucatu/São Paulo, and housed in Biotherium of Small Mammals of the Morphology Department, Institute of Biosciences, State University of São Paulo. During the experiment, animals were allocated in polypropylene cages $(43 \mathrm{~cm} \times 30 \mathrm{~cm} \times 15 \mathrm{~cm})$ with laboratory-grade pine shavings as bedding. Rats were maintained under controlled temperature $\left( \pm 23^{\circ} \mathrm{C}\right)$ and lighting conditions $(12 \mathrm{~L}$, 12D photoperiod, lights switched off at 07:00 pm). Rat chow and filtered tap water were provided ad libitum. Animals were allowed to adapt for at least 1 week before the beginning of the experiment. Experimental procedures were in accordance with the Ethical Principles in Animal Research adopted by the Brazilian College of Animal Experimentation and were approved by the Biosciences Institute/UNESP Ethics Committee for Animal Research (protocol number 06/07).

Male rats were randomly assigned to 2 different groups and treated for 42 days: The first group received daily intraperitoneal injections of $30 \mu \mathrm{g} / \mathrm{kg}$ leptin (recombinant rat leptin, Prepotechinc, ref: 400-21) dissolved in saline solution (Lep; $\mathrm{n}=12$ ), and the second, control group (C; $\mathrm{n}=12$ ), received just the vehicle. Rats were weighed on alternate days. The dose of leptin was chosen based on human serum leptin levels in obese individuals, according Haron and colleagues. ${ }^{26}$

\section{Collection of Tissue and Organs}

On the day following the end of treatment, rats from leptin and control groups were slightly anesthetized with $\mathrm{CO}_{2}$ and killed by decapitation. Blood was collected from the ruptured cervical vessels for determination of leptin and sexual hormones levels. The left testis, epididymis, vas deferens, ventral prostate, and seminal vesicle (without the coagulating gland) were removed, and their weights (absolute and relative to body weights) were determined. Testis and epididymis were used for sperm counts. The right testes were collected for parenchyma testosterone assay. The right epididymal cauda was used for sperm collection to artificial in utero insemination and sperm motility assay.

\section{Parenchyma Testosterone Assay}

The right testis of each animal was removed and decapsulated, and the parenchyma was sliced into $\sim 50-\mathrm{mg}$ pieces. Each piece was weighed and placed into a $1.5-\mathrm{mL}$ micro tube containing $1.0 \mathrm{~mL}$ of Medium 199 (M199). The M199 (M199, Earles - Invitrogen, ref.31100035; New York, USA) was buffered with $0.71 \mathrm{~g} / \mathrm{L}$ sodium bicarbonate $\left(\mathrm{NaHCO}_{3}\right)$ and $2.1 \mathrm{~g} / \mathrm{L}$ Hepes and contained $0.1 \%$ bovine serum albumine and $25 \mathrm{mg} / \mathrm{L}$ soybean trypsin inhibitor, $\mathrm{pH}$ 7.4. Concentration of testosterone was assessed by incubating parenchyma in duplicate, for 2 hours at $34^{\circ} \mathrm{C} .{ }^{27}$ After centrifugation (5 minutes, 10 $000 \times g$ ), medium was frozen at $-70^{\circ} \mathrm{C}$ until testosterone assay, as described subsequently. 


\section{Serum Testosterone, Follicle-Stimulating hormone, Luteinizing Hormone, and Leptin Levels}

The serum was obtained by blood centrifugation ( $2400 \mathrm{rpm}$, for 20 minutes at $4^{\circ} \mathrm{C}$ ). The concentrations of testosterone, luteinizing hormone $(\mathrm{LH})$, and follicle-stimulating hormone (FSH) were determined by the technique of double antibody radioimmunoassay. Testosterone doses were accomplished using the TESTOTERONE MAIA kit (Biochem Immunosystems, INC, k955102; Pennsylvania, USA). The LH and FSH doses used specific kits supplied by the National Institute of Arthritis, Diabetes and Kidney Diseases (NIDDK, Bethesda, MD 20892-2560). All samples were dosed in the same assay to avoid interassay errors. The intraassay error was $3.4 \%$ for $\mathrm{LH}, 2.8 \%$ for $\mathrm{FSH}$, and $4 \%$ for testosterone. The dosage of leptin levels was performed using the Rat Leptin ELISA Kit (Millipore Corporation, Billerica, Massachusetts, Cat. \# EZRL-83K) following the manufacturer's instructions.

\section{In Utero Artificial Insemination}

Because rats produce and ejaculate an excess of qualitatively normal sperm, artificial in utero insemination of a fixed critical number of sperm has been applied as a strategy to increase the sensitivity of the fertility test in toxicant-exposed rats. ${ }^{28}$ According to this technique, 5 million sperm collected in the cauda epididymis is inseminated directly into the uterus allowing evaluation of sperm quality, without the interference of other factors such as alterations in the sexual behavior pattern and number of sperm available for ejaculation. ${ }^{29}$

A cohort of females $(n=36)$ were synchronized with a single subcutaneous injection of $80 \mu \mathrm{g}$ of luteinizingreleasing hormone agonist (Sigma Chemical Co, St Louis, Missouri), 115 hours prior to the insemination. Shortly after the room lights were turned off on the day of proestrus, the synchronized females were paired for 1 hour with sexually experienced vasectomized males of proven sterility. Receptive females (that exhibited lordosis) were selected for insemination. The isolation and preparation of proximal cauda sperm for insemination were the same as described previously, ${ }^{30,31}$ with the following adaptations. Briefly, the sperm were released from the proximal cauda by nicking the duct with a $\mathrm{n}^{\circ} 11$ scapel and allowed to disperse in $2 \mathrm{~mL}$ of modified Human Tubular Fluid medium (ref. 90126, IrvineScientific, CA, USA). After 5 minutes of dispersion, a sperm aliquot was diluted 1:10 with fixative (10\% formalin in phosphate buffered sulfate) and counted using a Neubauer chamber. Within 15 minutes, each uterine horn was injected with a volume containing $5 \times 10^{6}$ sperm, a value that typically results in $75 \%$ fertility using control males rats. ${ }^{23}$ One female was inseminated per male. All inseminations were performed while the recipient female was in a surgical plane using a mix of ketamine and xylazine anesthesia. The bifurcation of the uterine horns was exposed through a low, midventral incision. Fine-curved forceps were used to elevate each horn, while the insemination volume was injected through the wall of each horn via an 18-gauge intravenous catheter attached to a 1.0$\mathrm{mL}$ syringe. Each injection site was cauterized immediately upon withdrawal of the needle. When insemination was complete, the abdominal musculature was sutured. Females were killed 20 days later to evaluate fertility.

\section{Fertility Evaluation}

On gestational day 20 , the females were slightly anesthetized with $\mathrm{CO}_{2}$ and killed by decapitation. After collection of the uterus and ovaries, the numbers of corpora lutea, implants, reabsorptions and live and dead fetuses were determined. From these results, the following parameters were calculated: gestation rate-number of pregnant females/number of inseminated females $\times 100$; fertility potential (efficiency of implantation) - implantation sites/ corpora lutea $\times 100$; rate of preimplantation loss $-[$ (number of corpora lutea - number of implantations)/number of corpora lutea $] \times 100$; rate of postimplantation loss- $-[$ number of implantations - number of live fetuses)]/number of implantations $\times 100 .{ }^{32}$

\section{Sperm Motility}

Sperm motility was evaluated in the same sample used for in utero insemination. An aliquot of $10 \mu \mathrm{L}$ was pipetted and transferred to a warmed $\left(34^{\circ} \mathrm{C}\right)$ Makler counting chamber (Sefi-Medical, Haifa, Israel). Sperm motility evaluation was performed by the same person throughout the study and was assessed by visual estimation (100 spermatozoa per animal, in duplicate) under a phase-contrast microscope (mod. Leica DMLS) at $200 \times$ magnification. Spermatozoa were classified as immotile, motile without progression and motile with progressive movement. ${ }^{7}$

\section{Daily Sperm Production Per Testis and Sperm Number in the Epididymis}

Homogenization-resistant testicular spermatids (stage 19 of spermiogenesis) in the testis were counted as described previously by Robb and colleagues, ${ }^{33}$ with adaptations adopted by Fernandes and coauthors. ${ }^{34}$ Briefly, the testis, decapsulated and weighed soon after collection, was homogenized in $5 \mathrm{~mL}$ of $\mathrm{NaCl} 0.9 \%$ containing Triton X $1000.5 \%$, followed by sonication for 30 seconds. After a 10-fold dilution, 1 sample was transferred to Neubauer chambers (4 fields per animal), and late spermatids were counted. To calculate the daily sperm production (DSP), the number of homogenization-resistant spermatids was divided by 6.1 , the number of days these spermatids are present in the seminiferous epithelium. In the same manner, caput/corpus and cauda epididymis portions were cut into small fragments with scissors and homogenized, and sperm counted as described for the testis. 

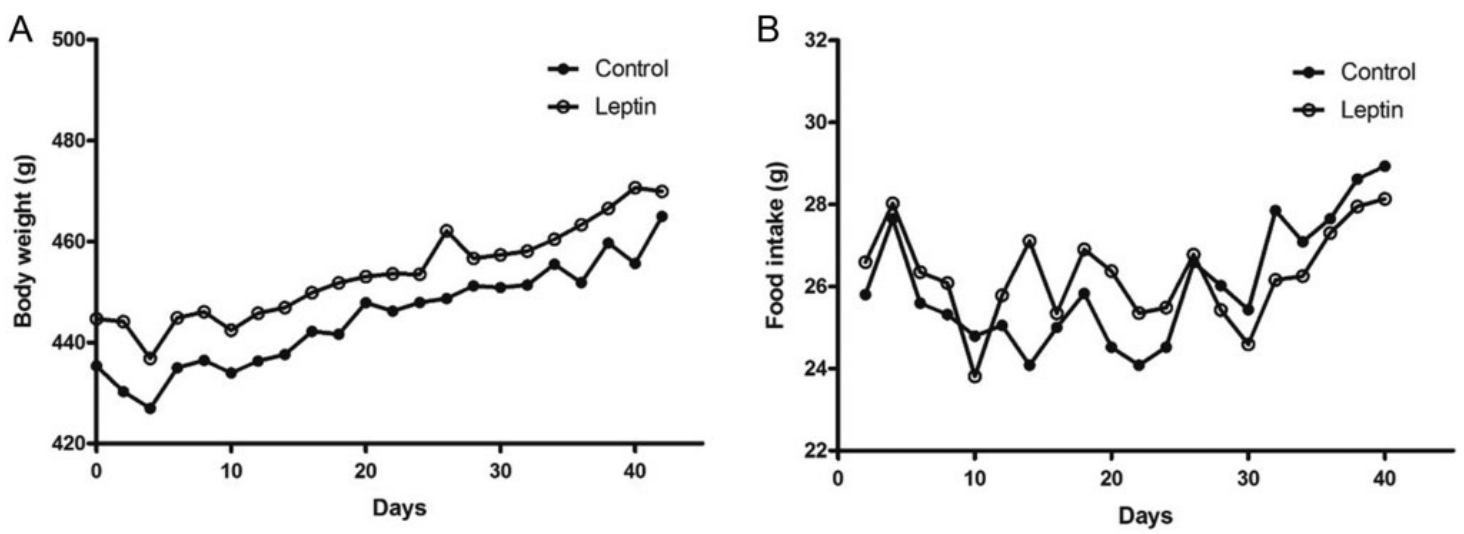

Figure I. Evolution of body weight (A) and food intake (B) during the 42 days of treatment in control and leptin groups.

Table I. Final Body and Organ Weights from Control and LeptinTreated Rats, After 42 Days of Treatment. ${ }^{a}$

\begin{tabular}{lrr}
\hline & Control & \multicolumn{1}{c}{ Leptin } \\
\hline Final body weight & $465.01 \pm 12.91$ & $469.93 \pm 12.72$ \\
Testis, g & $1.81 \pm 0.07$ & $1.79 \pm 0.06$ \\
Epididymis, $\mathrm{mg}$ & $679.40 \pm 22.65$ & $696.39 \pm 16.90$ \\
Vas deferens, $\mathrm{mg}$ & $94.56 \pm 4.00$ & $95.41 \pm 2.45$ \\
Ventral prostate, $\mathrm{mg}$ & $544.63 \pm 31.40$ & $550.86 \pm 29.14$ \\
Full seminal vesicle, $\mathrm{g}$ & $\mathrm{I} .10 \pm 0.10$ & $\mathrm{I} .12 \pm 0.07$ \\
Empty seminal vesicle, $\mathrm{mg}$ & $477.66 \pm 62.14$ & $419.7 \mathrm{I} \pm 24.82$ \\
$\mathrm{~N}$ & $\mathrm{I}$ & $\mathrm{I}$
\end{tabular}

${ }^{\text {a } V a l u e s ~ e x p r e s s e d ~ b y ~ m e a n ~} \pm$ standard error of the mean (SEM).

Student $t$ test.

\section{Statistical Analysis}

For comparison of results between the experimental groups, Student $t$ test or nonparametric Mann-Whitney $U$ test was performed, according to the characteristics of each variable. Differences were considered significant when $P<.05$. The statistical analyses were performed by GraphPadInStat (version 3.02).

\section{Results}

Throughout the course of the experiment, body weight and the average of food intake were similar between the experimental groups (Figure 1A and B, respectively) as well as the final body weight (Table 1). Reproductive organ weights also did not show any differences between control and leptin-treated rats (Table 1).

After 42 days of treatment, serum leptin was similar between control and leptin-treated rats (Table 2). In the same way, serum sex hormones - testosterone, FSH, and LH-levels were not altered by leptin exposure. On the other hand, parenchyma testosterone was decreased about $49 \%$ in leptintreated rats $($ control $=27.23 \pm 5.18$; leptin $=14.12 \pm 2.26$, mean \pm standard error of the mean [SEM]; $P<.05$; Table 2 ).
Table 2. Serum Leptin and Sexual Hormone Levels and Parenchyma Testosterone of Control and Leptin-Treated Rats After 42 Days of Treatment. $^{\mathrm{a}}$

\begin{tabular}{lcc}
\hline & Control & Leptin \\
\hline Serum leptin, $\mathrm{ng} / \mathrm{mL}$ & $7.14 \pm 0.48(\mathrm{n}=1 \mathrm{II})$ & $6.57 \pm 0.60(\mathrm{n}=9)$ \\
Serum LH, $\mathrm{ng} / \mathrm{mL}$ & $1.97 \pm 0.46(\mathrm{n}=1 \mathrm{II})$ & $2.14 \pm 0.64(\mathrm{n}=12)$ \\
Serum FSH, $\mathrm{ng} / \mathrm{mL}$ & $8.44 \pm 0.34(\mathrm{n}=12)$ & $8.26 \pm 0.52(\mathrm{n}=12)$ \\
Serum testosterone, & $1.66 \pm 0.35(\mathrm{n}=12)$ & $1.32 \pm 0.15(\mathrm{n}=12)$ \\
$\quad \mathrm{ng} / \mathrm{mL}$ & & \\
$\begin{array}{l}\text { Parenchyma } \\
\quad \text { testosterone, } \mathrm{ng} / \mathrm{g}\end{array}$ & $27.48 \pm 5.19(\mathrm{n}=1 \mathrm{II})$ & $14.01 \pm 2.26^{\mathrm{b}}(\mathrm{n}=1 \mathrm{I})$ \\
& &
\end{tabular}

Abbreviations: $\mathrm{LH}$, luetinizing hormone; FSH, follicle-stimulating hormone; SEM, standard error of the mean.

${ }^{a} V$ alues expressed by mean \pm SEM. Unpaired $t$ test with Welch correction. ${ }^{\mathrm{b}} \mathrm{P}<.05$.

The number of mature spermatids and DSP in the testis were not affected by treatment with leptin, likewise number of spermatozoa and transit time through epididymal caput/corpus or cauda were not (Table 3 ). In the same way, sperm motility also was not affected by treatment with exogenous leptin, and the percentages of progressive, nonprogressive, and immotile sperm were similar between the groups (Table 3).

After artificial insemination, gestational rate was $100 \%$ in the control group (8 pregnant/8 inseminated females) and $90 \%$ in the leptin-treated group ( 9 pregnant/10 inseminated female). There was a quantitative reduction in the uterus plus fetus weight (control $=46.23 \pm 3.79$; leptin $=28.96 \pm 7.80$, mean \pm SEM; $P=.08$ ), in the number of implantation sites $($ control $=10.13 \pm 0.67$; leptin $=6.56 \pm 1.56$, mean \pm SEM; $P=.06$ ), and in the number of live fetuses (control $=9.25 \pm$ 0.84 ; leptin $=5.56 \pm 1.56$, mean \pm SEM; $P=.09$; Table 4). Additionally, 2 died fetuses were found in the leptin group, and 1 of these presented an external malformation in the paws, while in the control group all fetuses were alive and with normal external morphology. Fertility potential showed a statically significant reduction, of about $40 \%$, in leptin-treated animals $($ control $=77.13 \pm 5.41$; leptin $=48.04 \pm 11.43$, mean \pm SEM; $P<.05)$, whereas the preimplantation loss rate was more 
Table 3. Sperm Counts and Sperm Motility in Control and LeptinTreated Rats After 42 Days of Treatment.

\begin{tabular}{|c|c|c|}
\hline & Control & Leptin \\
\hline \multicolumn{3}{|l|}{ Sperm counts } \\
\hline $\begin{array}{l}\text { Sperm number in the } \\
\text { testis, }\left(\times 10^{6}\right)^{\mathrm{a}}\end{array}$ & $186.18 \pm 11.42$ & $182.78 \pm 14.74$ \\
\hline $\begin{array}{l}\text { Daily sperm production } \\
\left(\times 10^{6} / \text { testis/day }\right)^{\mathrm{a}}\end{array}$ & $30.52 \pm 1.87$ & $29.97 \pm 2.42$ \\
\hline $\begin{array}{l}\text { Sperm number in the } \\
\text { caput/corpus } \\
\text { epididymis }\left(\times 10^{6}\right)^{\mathrm{a}}\end{array}$ & $164.39 \pm 9.45$ & $165.55 \pm 9.04$ \\
\hline $\begin{array}{l}\text { Sperm transit time in the } \\
\text { caput/corpus, days }{ }^{\mathrm{a}}\end{array}$ & $5.59 \pm 0.51$ & $6.00 \pm 0.63$ \\
\hline $\begin{array}{l}\text { Sperm number in the } \\
\text { cauda epididymis }\left(\times 10^{6}\right)^{a}\end{array}$ & $289.34 \pm 15.76$ & $296.75 \pm 19.11$ \\
\hline $\begin{array}{l}\text { Sperm transit time in the } \\
\text { cauda, days }{ }^{\mathrm{a}}\end{array}$ & $9.71 \pm 0.64$ & $10.63 \pm 1.07$ \\
\hline $\mathrm{N}$ & 12 & 12 \\
\hline \multicolumn{3}{|l|}{ Sperm motility, \% } \\
\hline $\begin{array}{l}\text { Motile with progressive } \\
\text { movement }\end{array}$ & $80(77-82)$ & $79(78.25-84)$ \\
\hline $\begin{array}{l}\text { Motile without progressive } \\
\text { movement }^{b}\end{array}$ & $15(13.5-15.75)$ & $14(12.25-16)$ \\
\hline Immotile & $5(3-6.25)$ & $5(4-8.75)$ \\
\hline $\mathrm{N}$ & 8 & 10 \\
\hline
\end{tabular}

${ }^{a}$ Values expressed by mean \pm standard error of the mean (SEM). Student $t$ test.

${ }^{b}$ Values expressed by median (QI- Q3). Mann-Whitney $U$ test.

Table 4. Fertility Parameters After In Utero Artificial Insemination of Rats From Control and Leptin-Treated Groups After 42 Days of Treatment. $^{\text {a }}$

\begin{tabular}{lrc}
\hline & Control & Leptin \\
\hline Body weight of dams, g & $354.65 \pm 7.68$ & $336.16 \pm 10.44$ \\
Uterus + fetuses weight, g & $46.23 \pm 3.79$ & $28.96 \pm 7.80$ \\
Number of corpora lutea & $13.25 \pm 0.49$ & $13.67 \pm 0.58$ \\
Number of implantation sites & $10.13 \pm 0.67$ & $6.56 \pm 1.56$ \\
Number of fetuses per litter & $9.25 \pm 0.84$ & $5.78 \pm 1.65$ \\
Number of alive fetuses per litter & $9.25 \pm 0.84$ & $5.56 \pm 1.73$ \\
Fertility potential, \% & $77.13 \pm 5.41$ & $48.04 \pm 11.43^{\mathrm{a}}$ \\
Preimplantation loss, \% & $22.87 \pm 5.41$ & $51.96 \pm 11.43^{\mathrm{a}}$ \\
Postimplantation loss, \% & $9.40 \pm 3.92$ & $35.31 \pm 13.33$ \\
$\mathrm{~N}$ & 8 & 9
\end{tabular}

${ }^{a} V a l u e s$ expressed by mean \pm standard error of the mean (SEM). The values in percentage were transformed into arc sine prior to statistical analysis.

${ }^{b} P<.05$. Student $t$ test.

than 2-fold higher in these animals (control $=22.87 \pm 5.41$; leptin $=51.96 \pm 11.43$, mean \pm SEM; $P<.05$; Table 4$)$.

\section{Discussion}

Leptin is well known to be the hormonal link between energy stores and several vital functions. Furthermore, it plays an important role in reproduction both in male and in female; however, the action of leptin on male reproduction is still unclear. Although it is documented that leptin supplementation in leptin-deficient states results in improved reproductive function, it is, however, also possible that when in excess, leptin could have some adverse effects on reproduction. ${ }^{26}$

Actually, recent studies have shown that leptin negatively affects male reproduction, being hyperleptinemia associated with low levels of testosterone, both in $\operatorname{man}^{35}$ and rats, ${ }^{36}$ reduction of sperm motility in rats, ${ }^{36,7}$ and infertility and oligozoospermia in man. ${ }^{37}$ Furthermore, Martins and coauthors ${ }^{11}$ showed that leptin modulates the nutritional support of spermatogenesis, modulating the metabolism of Sertoli cells, which could indicate a mechanism of action for the role of leptin in male reproduction.

When genetic obese mice $(o b / o b)$, that present decreased circulating leptin levels, are treated with this hormone, the body weight of the animals decreases throughout the treatment. ${ }^{14,15}$ However, treatment with exogenous leptin in normal rats does not alter body weight or food intake, ${ }^{26}$ also shown herein. In those homozygous mice $(o b / o b)$, the testis and seminal vesicles are smaller than in the lean mice, ${ }^{38}$ and treatment with exogenous leptin restores their weights. ${ }^{15}$ The leptin treatment in normal animals as in the current study did not change weight of reproductive organs and serum testosterone levels, indicating that this treatment did not induce general toxicity to the reproductive system.

Daily administration of leptin, in this study, did not lead to increased serum levels of leptin, which corroborates the data of Haron and colleagues ${ }^{26}$; this fact is probably due to the short half-life of leptin, approximately 10 minutes. Unlike our results, which did not show alteration in gonadotropin ( $\mathrm{LH}$ and FSH) levels, in other studies the leptin treatment of nonobese rats showed increased levels of LH and FSH. ${ }^{26,36}$ Generally, elevated levels of serum leptin are related to reduced levels of testosterone in both men and rodents. ${ }^{22,39-42}$ In obese men, basal and LH-stimulated androgen levels are reduced and inversely correlated with circulating leptin. ${ }^{35}$ SpragueDawley nonobese rats treated with exogenous leptin showed significant reduction in testosterone levels. ${ }^{36}$ On the other hand, our previous study showed high leptin levels in rats fed high-fat diet for 15 weeks, without increase in testosterone levels. ${ }^{7}$ So the action of hyperleptinemia on testosterone levels is still confusing in the literature. Although we did not find changes in serum testosterone levels after leptin treatment, a decrease of about $49 \%$ in parenchyma testosterone was observed, showing a direct action of leptin in testosterone production by Leydig cells. Indeed, in vitro study showed that leptin can significantly decrease basal and human chorionic gonadotrophin-induced testosterone secretion in the testes of adult rats, ${ }^{4,43}$ which is associated with the presence of leptin receptor in Leydig cells. ${ }^{43}$ The low concentration of parenchymal testosterone was not able to alter serum testosterone levels, but this reduction in parenchymal levels of the hormone may have affected local role of the testosterone.

Haron and coworkers, ${ }^{26}$ treating nonobese male rats with daily injections of 5,10 , and $30 \mu \mathrm{g} / \mathrm{kg}$ of leptin for 42 days, observed a significant reduction in epididymal sperm count and a significant increase in the percentage of abnormal sperm in 
treated animals. Contrasting to these results, in the present study, no change was observed in epididymal sperm counts. Alterations in sperm counts in the testis were also not observed, but no data in the literature about sperm production in animals treated with leptin were found. The number of spermatids in the testis and the total DSP are important indicators of male fertility capacity ${ }^{44}$ and also reflect the normal spermatogenesis. So, in the conditions of present study, leptin treatment apparently did not affect spermatogenesis, but more studies are needed to fully understand the role of leptin in testicular function. It is already known that the relationship between Sertoli cells and developing germ cells is essential for spermatogenesis. Martins and coauthors ${ }^{11}$ studying human Sertoli cells in culture demonstrated that leptin can affect the nutritional role of these cells, responsible for lactate production, the preferred substrate of germ cells, which might alter spermatogenesis. In mice, the leptin treatment led to altered spermatogenesis, based on morphological analysis. ${ }^{45}$

In men, seminal plasma leptin concentration is negatively associated with the percentage of motile spermatozoa, what may indicate an involvement of the hormone in the mechanisms of motility development. ${ }^{46}$ However, the serum leptin levels show no relationship with rapid progressive motility. ${ }^{47}$ Treatment of nonobese Sprague-Dawley rats with leptin reduced the percentage of progressive motile sperm, ${ }^{36}$ in contrast to present study, where leptin treatment did not alter the motility pattern of sperm.

The lack of leptin is a well-known cause of infertility in the genetically obese mice ${ }^{3,9}$ and is also known that the replacement of this hormone restores the fertility in that animals, in both sexes. ${ }^{14,15}$ Although our study had not shown any alterations in sperm parameters, it showed a significant reduction in fertility potential, that is, in the implantation efficiency, after artificial insemination. In animals that were exposed to exogenous leptin, there was a quantitative reduction in number of implantation sites that were reflected in the fertility potential, which was reduced to $60 \%$ compared to control animals. In utero artificial insemination is a technique used to evaluate sperm quality, since it increases the sensitivity of fertility test. The result found in this study indicates that leptin exposure affected sperm quality, causing a reduction in implantation rate, that is, in the ability to generating offspring. Indeed, the increased preimplantation loss rate found in the present study indicates that, either spermatozoa from treated animals were not able to fertilize the oocyte or they have some genetic alteration that did not allow postfertilization development. SpragueDawley nonobese rats treated with leptin showed increased DNA fragmentation, ${ }^{36}$ which could explain, at least in part, the fertility problems described herein.

Taking into account that the reproductive potential of rats is higher compared to other animals including men, the impairment of fertility capacity showed in the present study after leptin exposure can also indicate that high levels of leptin (as found in obesity) may affect human fertility. Indeed, human clinical studies have shown that high levels of leptin in serum and seminal plasma are related to infertility in oligozoospermic men, ${ }^{37}$ although the mechanism is not understood.

In conclusion, the results of this study indicate that leptin administration to nonobese male rats impairs the ability of treated animals to generate offspring, since the occurrence of implantation was diminished. So we demonstrated that leptin impair sperm quality, affecting the reproductive capacity. Taking together, our results suggest the occurrence of DNA damage in sperm as a possible mechanism, but further studies are needed in this direction.

\section{Acknowledgments}

The authors are grateful to Dr Janete Aparecida Anselmo Franci and Dr Ruither de Oliveira Gomes Carolino for the hormonal dosages. We are also grateful to Camila Corrêa-Camacho and Dijon Campos for help in leptin dosage.

\section{Authors' Note}

C.D.B.F. and W.D.G.K. designed the study. C.D.B.F. was involved in all study, which represents part of her $\mathrm{PhD}$ thesis presented to the State University of Campinas-UNICAMP, Brazil, under orientation of W.D.G.K. C.D.B.F., G.S.A.F., J.E.P., A.P.A.F., and M.S. participated in all experimental work and data analyses; C.D.B.F. performed the interpretation of data and drafted manuscript, which was reviewed and approved by all authors.

\section{Declaration of Conflicting Interests}

The author(s) declared no potential conflicts of interest with respect to the research, authorship, and/or publication of this article.

\section{Funding}

The author(s) disclosed receipt of the following financial support for the research, authorship, and/or publication of this article: This work was supported by the State of São Paulo Research Foundation (FAPESP - grant number: 06/61815-8) and the National Council for Scientific and Technological Development (CNPq-grant number 140558/2007-1).

\section{References}

1. Bellefontaine N, Elias CF. Minireview: metabolic control of the reproductive physiology: Insights from genetic mouse models. Horm Behav. 2014;66(1):7-14.

2. Bellefontaine N, Chachlaki K, Parkash J, Vanacker C, et al. Leptin-dependent neuronal NO signaling in the preoptic hypothalamus facilitates reproduction. J Clin Invest. 2014;124(6): 2550-2559.

3. Messinis IE, Milingos SD. Leptin in human reproduction. Hum Reprod Update. 1999;5(1):52-63.

4. Tena-Sempere M, Pinilla L, González LC, Diéguez C, Casanueva FF, Aguilar E. Leptin inhibits testosterone secretion from adult rat testis in vitro. J Endocrinol. 1999;161(2):211-218.

5. Auwerx J, Staels B. Leptin. Lancet. 1998;351(9104):737-742.

6. Handjieva-Darlenska T, Boyadjieva N. The effect of high-fat diet on plasma ghrelin and leptin levels in rats. $J$ Physiol Biochem. 2009;65(2):157-164. 
7. Fernandez CD, Bellentani FF, Fernandes GS, et al. Diet-induced obesity in rats leads to a decrease in sperm motility. Reprod Biol Endocrinol. 2011;9:32.

8. Aizawa-Abe M, Ogawa Y, Masuzaki H, et al. Pathophysiological role of leptin in obesity-related hypertension. J Clin Invest. 2000; 105(9):1243-1252.

9. Tena-Sempere M, Barreiro ML. Leptin in male reproduction: the testis paradigm. Mol Cell Endocrinol. 2002;188(1-2):9-13.

10. Teerds KJ, de Rooij DG, Keijer J. Functional relationship between obesity and male reproduction: from humans to animal models. Hum Reprod Update. 2011;17(5):667-683.

11. Martins AD, Moreira AC, Sá R, et al. Leptin modulates human Sertoli cells acetate production and glycolytic profile: a novel mechanism of obesity-induced male infertility? Biochim Biophys Acta. 2015;1852(9):1824-1832.

12. Ni K, Steger K, Yang H, Wang H, Hu K, Chen B. Expression and role of leptin under hypoxic conditions in human testis: organotypic in vitro culture experiment and clinical study on patients with varicocele. J Urol. 2015;193(1):360-367.

13. Chen B, Guo JH, Lu YN, et al. Leptin and varicocele-related spermatogenesis dysfunction: animal experiment and clinical study. Int J Androl. 2009;32(5):532-541.

14. Chehab FF, Lim ME, Lu R. Correction of the sterility defect in homozygous obese female mice by treatment with the human recombinant leptin. Nat Genet. 1996;12(3):318-320.

15. Mounzih K, Lu R, Chehab FF. Leptin treatment rescue the sterility of genetically obese ob/ob males. Endocrinology. 1997; 138(3):1190-1193.

16. Sone M, Osamura RY. Leptin and pituitary. Pituitary. 2001; 4(1-2):15-23.

17. Schoeller EL, Chi M, Drury A, Bertschinger A, Esakky P, Moley KH. Leptin monotherapy rescues spermatogenesis in male Akita type 1 diabetic mice. Endocrinology. 2014; 155(8):2781-2786.

18. Vendramini V, Cedenho AP, Miraglia SM, Spaine DM. Reproductive function of the male obese Zucker rats: alteration in sperm production and sperm DNA damage. Reprod Sci. 2014;21(2): 221-229.

19. Barash IA, Cheung CC, Weigle DS, et al. Leptin is a metabolic signal to the reproductive system. Endocrinology. 1996;137(7): 3144-3147.

20. Cunningham MJ, Clifton DK, Steiner RA. Leptin's actions on the reproductive axis: perspectives and mechanisms. Biol Reprod. 1999;60(2):216-222.

21. Magnusdottir EV, Thorsteinsson T, Thorsteinsdottir S, Maria Heimisdottir M, Olafsdottir K. Persistent organochlorines, sedentary occupation, obesity and human male subfertility. Hum Reprod. 2005;20(1):208-215.

22. Jensen TK, Andersson AM, Jørgensen N, et al. Body mass index in relation to semen quality and reproductive hormones among 1,558 Danish men. Fertil Steril. 2004;82(4):863-870.

23. Kort HI, Massey JB, Elsner CW, et al. Impact of body mass index values on sperm quantity and quality. J Androl. 2006;27(3): 450-452.

24. Alves MG, Jesus TT, Sousa M, Goldberg E, Silva BM, Oliveira PF. Male fertility and obesity: are ghrelin, leptin and glucagon- like peptide-1 pharmacologically relevant? Curr Pharm Des. 2016;22(7):783-791.

25. Landry D, Cloutier F, Martin Luc J. Implications of leptin in neuroendocrine regulation of male reproduction. Reprod Biol. 2013;13(1):1-14.

26. Haron MN, D’Souza UJA, Jaafar H, Zakaria R, Singh HJ. Exogenous leptin administration decreases sperm count and increases the fraction of abnormal sperm in adult rats. Fertil Steril. 2010; 93(1):322-324.

27. Laskey JW, Klinefelter GR, Kelce WR, Ewing LL. Effect of ethane dimethanesulphonate on adult and immature rabbit Leydig cells: comparison with EDS treated rat Leydig cells. Biol Reprod. 1994;50(5):1151-1160.

28. Amann RP. Use of animal models for detecting specific alterations in reproduction. Fundam Appl Toxicol. 1982; 2(1):13-26.

29. Klinefelter GR. Actions of toxicants on the structure and function of the epididymis. In: Robaire B, Hinton BT, eds. The Epididymis - From Molecules to Clinical Pratice. 1st ed. New York, NY: Kluwer Academic/Plenum Publisher; 2002:353-369.

30. Klinefelter GR, Laskey JW, Perreault SD, et al. The ethane dimethanesulphonate-induced decrease in the fertilizing ability of cauda epididymal sperm is independent of the testis. $J$ Androl. 1994,15(4):318-327.

31. Kempinas WG, Suarez JD, Roberts NL, et al. Fertility of rat epididymal sperm after chemically and surgically induced sympathectomy. Biol Reprod. 1998;59(4):897-904.

32. Fernandez CD, Porto EM, Arena AC, Kempinas WD. Effects of altered epididymal sperm transit time on sperm quality. Int $J$ Androl. 2008;31(4):427-437.

33. Robb GW, Amman RP, Killian GJ. Daily sperm production and epididymal sperm reserves of puberal and adult rats. $J$ Reprod Fertil. 1978;54(1):103-107.

34. Fernandes GS, Arena AC, Fernandez CDB, Mercadante A, Barbisan LF, Kempinas WG. Reproductive effects in male rats exposed to diuron. Reprod Toxicol. 2007;23(1):106-112.

35. Isidori AM, Caprio M, Strollo F, et al. Leptin and androgens in male obesity: evidence for leptin contribution to reduced androgen levels. J Clin Endocrinol Metab. 1999;84(10): 3673-3680.

36. Abbasihormozi S, Shahverdi A, Kouhkan A, Cheraghi J, Akhlaghi AA, Kheimeh A. Relationship of leptin administration with production of reactive oxygen species, sperm DNA fragmentation, sperm parameters and hormone profile in the adult rat. Arch Gynecol Obstet. 2013;287(6):1241-1249.

37. Hanafy S, Halawa FA, Mostafa FA, Mikhael NW, Khalil KT. Serum leptin correlates in infertile oligozoospermic males. Andrologia. 2007;39(5):177-180.

38. Bhat GK, Sea TL, Olatinwo MO, et al. Influence of a leptin deficiency on testicular morphology, germ cell apoptosis, and expression levels of apoptosis-related genes in the mouse. $J$ Androl. 2006;27(2):302-310.

39. Aggerholm AS, Thulstrup AM, Toft G, Ramlau-Hansen $\mathrm{CH}$, Bonde JP. Is overweight a risk factor for reduced semen quality and altered serum sex hormone profile? Fertil Steril. 2008,90(3): 619-626. 
40. Bakos HW, Mitchell M, Setchell BP, Lane M. The effect of paternal diet induced obesity on sperm function and fertilization in a mouse model. Int J Androl. 2010;34(5 pt 1):402-410.

41. Chavarro JE, Toth TL, Wright DL, Meeker JD, Hauser R. Body mass index in relation to semen quality, sperm DNA integrity, and serum reproductive hormone levels among men attending an infertility clinic. Fertil Steril. 2010,93(7): 2222-2231.

42. Vigueras-Villaseñor RM, Rojas-Castañeda JC, Chávez-Saldaña $\mathrm{M}$, et al. Alterations in the spermatic function generated by obesity in rats. Acta Histochem. 2011;113(2):214-220.

43. Caprio M, Fabbrini E, Ricci G, et al. Ontogenesis of leptin receptor in rat Leydig cells. Biol Reprod. 2003;68(4): 1199-1207.
44. Ashby J, Tinwell H, Lefevre PA, Joiner R, Haseman J. The effect on sperm production in adult Sprague-Dawley rats exposed by gavage to bisfenol A between postnatal days 91-97. Toxicol Sci. 2003;74(1):129-138.

45. Esmaili-Nejad MR, Babaei H, Kheirandish R. The effects of longterm leptin administration on morphometrical changes of mice testicular tissue. Iran J Basic Med Sci. 2015;18(12):1176-1182.

46. Glander HJ, Lammert A, Paasch U, Glasow A, Kratzsch J. Leptin exists in tubuli seminiferi and in seminal plasma. Andrologia. 2002;34(4):227-233.

47. Zorn B, Osredkar J, Meden-Vrtovec H, Majdic G. Leptin levels in infertile male patients are correlated with inhibin $\mathrm{B}$, testosterone and SHBG but not with sperm characteristics. Int J Androl. 2007; 30(5):439-444. 